\title{
Litsine A: A New Aporphine Alkaloid from the Root Barks of
}

\section{Litsea glutinosa}

\section{Yan Jin ${ }^{\oplus 1,2}$, Younan Wu ${ }^{\oplus 1,2}$, Yiying $\mathbf{L i}^{\oplus 3}$, Caiyun Zhang ${ }^{\oplus 2}$, Wanying Sun ${ }^{\oplus 1,2}$, Lin Dong ${ }^{\oplus * 1,2}$ and Xiaopo Zhang ${ }^{\circledR * 1,2}$}

\author{
${ }^{1}$ Hainan Provincial Key Laboratory of R\&D on Tropical Herbs, Hainan Medicinal University, \\ Haikou 571199, P.R.China \\ ${ }^{2}$ School of Pharmaceutical Sciences, Hainan Medicinal University, Haikou 571199, P.R.China \\ ${ }^{3}$ School of Basic Medicine and Life Science, Hainan Medicinal University, Haikou 571199, \\ P.R.China
}

(Received April 16, 2018; Revised June 26, 2018; Accepted July 01, 2018)

\begin{abstract}
A new aporphine alkaloid, named Litsine A, along with two known ones were isolated from the root barks of Litsea glutinosa. The new structure was determined by various spectroscopic techniques including 1D('H-, $\left.{ }^{13} \mathrm{C}-\mathrm{NMR}\right), 2 \mathrm{D}-\mathrm{NMR}(\mathrm{HMBC}, \mathrm{HSQC}, \mathrm{COSY}$ and ROESY) and high resolution electrospray ionization mass spectrometry (HR-ESI-MS), where as the structures of the known compounds were elucidated through 1DNMR, mass spectrometric analysis and compared with the reported data in literature. The effects of these compounds on glucose uptake in $\mathrm{C} 2 \mathrm{C} 12$ myotubes were evaluated at the concentration of $10 \mu \mathrm{M}$. The three compounds exhibited potent activity, with $\mathbf{1}$ as the best one, in increasing glucose uptake.
\end{abstract}

Keywords: Litsea glutinosa; Litsine A; aporphine alkaloids; glucose uptake activities. C 2018 ACG Publications. All rights reserved.

\section{Plant Source}

In the ongoing search of phytochemical studies of anti-diabetic plants distributed in Hainan Island, China. Herein, we report the isolation, structure elucidation and biological studies of a new aporphine alkaloid, Litsine A (1) along with two known compounds, boldine (2) [1] and laurolitsine (3)[2] (Figure 1), from the root barks of L. glutinosa. The investigated plant was collected from Wenchang City of Hainan Province, China, in October 2017, and authenticated by Prof. Niankai Zeng (School of Pharmaceutical Science, Hainan Medical University) according to the Flora of China. A voucher specimen (No.LG201710) was deposited at the herbarium of School of Pharmaceutical Science, Hainan Medical University.

\footnotetext{
${ }^{*}$ Corresponding authors: E- Mail: 729907108@qq.com (Lin Dong), Phone +86-898-5337; z xp1412@163.com (Xiaopo Zhang), Phone $+86+898-3826$.
}

The article was published by ACG Publications 


\section{Previous Studies}

L. glutinosa is a member of the genus Litsea in the Lauraceae family, which is widely distributed in subtropical and tropical regions. In China, this plant has been used as traditional medicine for treatment of many diseases [3,4]. Pharmacological investigations indicated that the leaves and barks of L. glutinosa possessed anti-bacterial, anti-inflammatory, anti-nociceptive, analgesic, and anti-diabetic properties [5,6]. Studies on chemical constituents have led to the isolation of lignans, alkaloids, etc $[7,8]$. Previously, we reported three new lignan glycosides and other known compounds from this plant $[9,10]$.

\section{Present Study}

The root barks of $L$. glutinosa $(7.0 \mathrm{~kg})$ were air-dried, cut into pieces, and were extracted with ethanol. The ethanol extract was concentrated under reduced pressure to give a residue $(660 \mathrm{~g})$. The residue was dissolved in water, and then its $\mathrm{pH}$ value was adjusted to 2 by adding $1 \% \mathrm{H}_{2} \mathrm{SO}_{4}$. The acidic solution was partitioned by chloroform to remove the lipid-soluble compounds. Then the $\mathrm{pH}$ value of the residue was adjusted to 10 by adding ammonium hydroxide. The $\mathrm{pH}$ of the ammonium hydroxide is 12 , and the concentration is $25 \%$. Then, ethyl acetate was used to extract the residue to give the alkaloid-rich extract $(55 \mathrm{~g})$ after concentration. The alkaloid-rich extract was separated by silica gel column chromatography using a gradient ratio of dichloromethane-acetone as the eluent to give five fractions (Fra1-Fra5). Fra.3 was further purified by Sephadex LH-20 to afford four fractions (subfra1-subfra4). Subfra.2 was purified by HPLC using a mixture of methanol-water (45:55) to afford Litsine A $(1,15 \mathrm{mg})$. Subfra3 was isolated by HPLC using a mixture of methanol-water (45:55) to give boldine $(2,10 \mathrm{mg})$ and laurolitsine $(3,8 \mathrm{mg})$.

Litsine A (1): Yellow powder $(\mathrm{MeOH}),[\alpha]^{\mathrm{D}}{ }_{25}=35(\mathrm{c} 0.05), \mathrm{UV}(\mathrm{MeOH}) \lambda \max (\log \varepsilon) 258 \mathrm{~nm} .{ }^{1} \mathrm{H}$ NMR $\left(600 \mathrm{MHz}, \mathrm{CD}_{3} \mathrm{OD}\right) \delta(\mathrm{ppm})=9.50(1 \mathrm{H}, \mathrm{s}, \mathrm{CHO}), 7.95(1 \mathrm{H}, \mathrm{s}, \mathrm{H}-11), 7.37(1 \mathrm{H}, \mathrm{d}, J=6.0 \mathrm{~Hz}$, H-2'), $6.78(1 \mathrm{H}, \mathrm{s}, \mathrm{H}-8), 6.65\left(1 \mathrm{H}, \mathrm{d}, J=6.0 \mathrm{~Hz}, \mathrm{H}-3^{\prime}\right), 6.52(1 \mathrm{H}, \mathrm{s}, \mathrm{H}-3), 4.18(1 \mathrm{H}, \mathrm{d}, J=12.0 \mathrm{~Hz}, \mathrm{H}-$ 5 'a), 4.01 (1H, d, J=12.0 Hz, H-5'b), $3.86(3 \mathrm{H}, \mathrm{s}, 10-\mathrm{OMe}), 3.57$ (3H, s, 1-OMe), $3.18(1 \mathrm{H}, \mathrm{m}, \mathrm{H}-5 \alpha)$, $3.16(1 \mathrm{H}, \mathrm{m}, \mathrm{H}-7 \alpha), 3.15(1 \mathrm{H}, \mathrm{m}, \mathrm{H}-6 \mathrm{a}), 2.98(1 \mathrm{H}, \mathrm{m}, \mathrm{H}-4 \alpha), 2.62(1 \mathrm{H}, \mathrm{m}, \mathrm{H}-4 \beta), 2.60(1 \mathrm{H}, \mathrm{m}, \mathrm{H}-5 \beta)$, $2.49(1 \mathrm{H}, \mathrm{m}, \mathrm{H}-7 \beta) .{ }^{13} \mathrm{C}$ NMR $\left(150 \mathrm{MHz}, \mathrm{CD}_{3} \mathrm{OD}\right) \delta(\mathrm{ppm})=144.9(\mathrm{C}, \mathrm{C}-1), 151.1(\mathrm{C}, \mathrm{C}-2), 115.6$ $(\mathrm{CH}, \mathrm{C}-3), 128.7$ (C, C-3a), $131.3(\mathrm{C}, \mathrm{C}-3 \mathrm{~b}), 30.3\left(\mathrm{CH}_{2}, \mathrm{C}-4\right), 51.9\left(\mathrm{CH}_{2}, \mathrm{C}-5\right), 60.8(\mathrm{CH}, \mathrm{C}-6 \mathrm{a}), 35.4$ $\left(\mathrm{CH}_{2}, \mathrm{C}-7\right), 127.5(\mathrm{C}, \mathrm{C}-7 \mathrm{a}), 116.4(\mathrm{CH}, \mathrm{C}-8), 147.7(\mathrm{C}, \mathrm{C}-9), 148.4(\mathrm{C}, \mathrm{C}-10), 113.3(\mathrm{CH}, \mathrm{C}-11)$, 131.4 (C, C-11a), 130.8 (C, C-11b), 154.6 (C, C-1'), 125.2 (CH, C-2'), 114.2 (CH, C-3'), 160.4 (C, C$\left.4^{\prime}\right), 52.0\left(\mathrm{CH}_{2}, \mathrm{C}-5^{\prime}\right), 61.1\left(\mathrm{CH}_{3}, 1-\mathrm{OMe}\right), 57.1\left(\mathrm{CH}_{3}, 10-\mathrm{OMe}\right), 179.8\left(\mathrm{CH}, 1^{\prime}-\mathrm{CHO}\right)$. HR-ESI-MS: $m / z 422.1599\left([\mathrm{M}+\mathrm{H}]^{+}\right.$, calcd. $\mathrm{C}_{24} \mathrm{H}_{24} \mathrm{NO}_{6}$ for 422.1604). $\mathrm{ESI}(+) \mathrm{MS}: m / z 422.1[\mathrm{M}+\mathrm{H}]^{+}, 297.1$, 284.1, 265.1, $109.2\left(\mathrm{C}_{6} \mathrm{H}_{5} \mathrm{O}_{2}^{+}\right)$.

Cell culture: $\mathrm{C} 2 \mathrm{C} 12$ myoblasts were maintained in DMEM supplemented with $10 \% \mathrm{FBS}$ at $37{ }^{\circ} \mathrm{C}$ and $5 \% \mathrm{CO} 2$. To induce differentiation, media was replaced with DMEM containing $2 \%$ horse serum when the cells reached confluence. The $\mathrm{C} 2 \mathrm{C} 12$ cells were kept in this differentiating medium for 5 days, which allowed cells to be fully differentiated and used in the following experiments.

Glucose uptake assay: Glucose uptake assay was performed as previously reported [11]. Briefly, differentiated $\mathrm{C} 2 \mathrm{C} 12$ myotubes were incubated with the serum-free DMEM containing the fluorescent glucose analog 2-NBDG $(10 \mu \mathrm{M})$ and various compounds $(10 \mu \mathrm{M})$ or insulin $(100 \mathrm{nM})$. After incubation for $12 \mathrm{~h}$, medium was removed and cells were washed with phosphate-buffered saline (PBS) twice. Cells were scraped out in $1 \mathrm{~mL}$ of PBS and transferred into $5 \mathrm{~mL}$ polystyrene roundbottom tubes (BD Falcon) and kept at $4{ }^{\circ} \mathrm{C}$. The amount of 2-NBDG taken up by the cells was measured by determining the fluorescence intensities at $\mathrm{Ex} / \mathrm{Em}=475 \mathrm{~nm} / 550 \mathrm{~nm}$ using a Tecan Infinite M1000Pro Microplate Reader (TECAN Group Ltd, Shanghai, China). 
The root barks of L. glutinosa were air-dried, cut into pieces, and were extracted with ethanolwater. The ethanol extract was concentrated under reduced pressure to give a residue. The residue was dissolved in water, and then its $\mathrm{pH}$ value was adjusted to 2 by adding $1 \% \mathrm{H}_{2} \mathrm{SO}_{4}$. The acidic solution was partitioned by chloroform to remove the lipid-soluble compounds. Then the $\mathrm{pH}$ value of the residue was adjusted to 10 by adding ammonia. Then, ethyl acetate was used to extract the basic solution, after concentration, to give the alkaloid-rich extract. Phytochemical investigation on alkaloidrich extract has resulted in the isolation of one new aporphine alkaloid, Litsine A (1) (Figure 1).

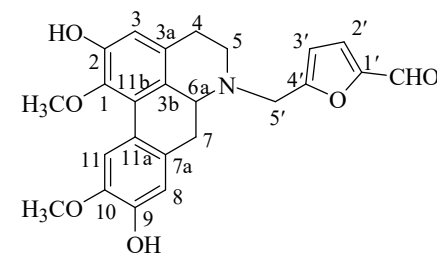

1

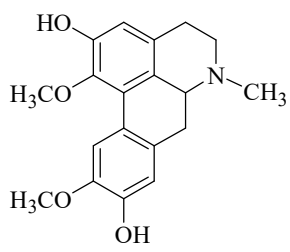

2

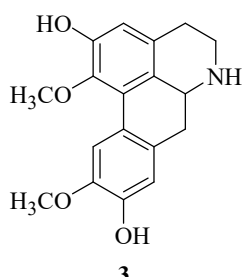

3

Figure 1. Structure of compounds 1-3 isolated from L. glutinosa

Compound 1, Litsine A, was obtained as yellow powder. Its molecular formula was established to be $\mathrm{C}_{24} \mathrm{H}_{23} \mathrm{NO}_{6}$ by interpretation of HRESIMS, requiring 14 degrees of unsaturation. The ${ }^{1} \mathrm{H}$ NMR spectrum showed notable signals attributing to two methoxy protons at $\delta_{\mathrm{H}} 3.57(3 \mathrm{H}, \mathrm{s}), 3.86(3 \mathrm{H}, \mathrm{s})$. Further examination of the spectrum revealed the existence of one aldehyde proton at $\delta=9.50(1 \mathrm{H}, \mathrm{s})$ and a set of aromatic protons at $\delta=6.65\left(1 \mathrm{H}, \mathrm{d}, J=6.0 \mathrm{~Hz}, \mathrm{H}-3^{\prime}\right), 7.37\left(1 \mathrm{H}, \mathrm{d}, J=6.0 \mathrm{~Hz}, \mathrm{H}-2^{\prime}\right), 6.52$ $(1 \mathrm{H}, \mathrm{s}, \mathrm{H}-3), 6.78(1 \mathrm{H}, \mathrm{s}, \mathrm{H}-8), 7.95(1 \mathrm{H}, \mathrm{s}, \mathrm{H}-11)$. Moreover, the two deshielded methylene protons at $\delta=3.18(1 \mathrm{H}, \mathrm{m}, \mathrm{H}-5 \alpha), 2.60(1 \mathrm{H}, \mathrm{m}, \mathrm{H}-5 \beta), 4.18\left(1 \mathrm{H}, \mathrm{d}, J=12.0 \mathrm{~Hz}, \mathrm{H}-5^{\prime} \mathrm{a}\right), 4.01(1 \mathrm{H}, \mathrm{d}, J=12.0$ $\left.\mathrm{Hz}, \mathrm{H}-5^{\prime} \mathrm{b}\right)$, and a methine proton at $\delta_{\mathrm{H}} 3.16(1 \mathrm{H}, \mathrm{m})$ were consistent with the presence of $N$-methylene and $\mathrm{N}$-methine. Its ${ }^{13} \mathrm{C}$ NMR alongside HSQC data showed signals for two methoxy groups, four methylenes, six methines, one aldehyde carbon, and eleven non-protonated carbons.

The ${ }^{1} \mathrm{H}-{ }^{1} \mathrm{H}$ COSY and HSQC spectra of 1 revealed the existence of three units as shown in Figure 2. The HMBC spectrum of 1 exhibited correlations from the aromatic proton at $\mathrm{H}-3\left(\delta_{\mathrm{H}} 6.52\right)$ to carbons at $\delta_{\mathrm{C}} 151.1(\mathrm{C}-2), \delta_{\mathrm{C}} 144.9(\mathrm{C}-1), \delta_{\mathrm{C}} 128.7(\mathrm{C}-3 \mathrm{a})$ and $\delta_{\mathrm{C}} 30.3(\mathrm{C}-4)$ and from the methylene proton at $\delta_{\mathrm{H}} 3.18(\mathrm{H}-5)$ to carbons at $\delta_{\mathrm{C}} 30.3(\mathrm{C}-4), \delta_{\mathrm{C}} 128.7(\mathrm{C}-3 \mathrm{a})$ and $\delta_{\mathrm{C}} 60.8(\mathrm{C}-6 \mathrm{a})$. The correlations from methylene protons at $\delta_{\mathrm{H}} 3.16,2.49(\mathrm{H}-7)$ to carbons at $\delta_{\mathrm{C}} 60.8(\mathrm{C}-6 \mathrm{a}), \delta_{\mathrm{C}} 131.3(\mathrm{C}-$ $3 \mathrm{~b}), \delta_{\mathrm{C}} 127.5(\mathrm{C}-7 \mathrm{a})$ and $\delta_{\mathrm{C}} 131.4(\mathrm{C}-11 \mathrm{a})$. The correlations from $\mathrm{H}-8\left(\delta_{\mathrm{H}} 6.78\right)$ to C-7 $\left(\delta_{\mathrm{C}} 35.4\right), \mathrm{C}-7 \mathrm{a}$ $\left(\delta_{\mathrm{C}} 127.5\right), \mathrm{C}-9\left(\delta_{\mathrm{C}} 147.7\right)$ and $\mathrm{C}-10\left(\delta_{\mathrm{C}} 148.4\right)$ and the correlations from $\mathrm{H}-11\left(\delta_{\mathrm{H}} 7.95\right)$ to $\mathrm{C}-10\left(\delta_{\mathrm{C}}\right.$ $148.4), \mathrm{C}-9\left(\delta_{\mathrm{C}} 147.7\right), \mathrm{C}-11 \mathrm{a}\left(\delta_{\mathrm{C}} 131.4\right)$ and $\mathrm{C}-11 \mathrm{~b}\left(\delta_{\mathrm{C}} 130.8\right)$ verified the connection from $\mathrm{C}-7$ to $\mathrm{C}-$ 11. These data indicated that $\mathbf{1}$ had an aporphine alkaloid skeleton similar to that of boldine $[1,10]$. However, some differences in the NMR signals for the side chain were observed. The HMBC spectrum of 1 exhibited correlations from H-3' $\left(\delta_{\mathrm{H}} 6.65\right)$ to $\mathrm{C}-1^{\prime}\left(\delta_{\mathrm{C}} 154.6\right), \mathrm{C}-2^{\prime}\left(\delta_{\mathrm{C}} 125.2\right)$ and C-4' $\left(\delta_{\mathrm{C}} 160.4\right)$ suggested the presence of a furan moiety and the aldehyde group was attached to C-1' $\left(\delta_{\mathrm{C}}\right.$ 154.6). Its ESI-MS spectrum suggested the presence of the furanoaldehyde moiety ( $\mathrm{m} / \mathrm{z} 109.2)$. The side-chain connectivity was deduced from the HMBC correlations from $\mathrm{H}-5^{\prime}\left(\delta_{\mathrm{H}} 4.01,4.18\right)$ to $\mathrm{C}-5\left(\delta_{\mathrm{C}}\right.$ $51.9), \mathrm{C}-6 \mathrm{a}\left(\delta_{\mathrm{C}} 60.8\right), \mathrm{C}-4^{\prime}\left(\delta_{\mathrm{C}} 160.4\right)$ and $\mathrm{C}-3^{\prime}\left(\delta_{\mathrm{C}} 114.2\right)$. These HMBC correlations also displayed that the furan moiety was attached to $\mathrm{C}-5^{\prime}$ and $\mathrm{C}-5^{\prime}$ was connected to the $N$ atom. Finally, the correlations from methoxy proton $\delta_{\mathrm{H}} 3.57(3 \mathrm{H}, \mathrm{s})$ to $\mathrm{C}-1\left(\delta_{\mathrm{C}} 144.9\right)$ and correlations from the methoxyl proton $\delta_{\mathrm{H}} 3.86(3 \mathrm{H}, \mathrm{s})$ to $\mathrm{C}-10\left(\delta_{\mathrm{C}} 148.4\right)$ together with the ROESY correlations between the protons at $\delta_{\mathrm{H}} 7.95(\mathrm{H}-11)$ and $\delta_{\mathrm{H}} 3.57\left(1-\mathrm{OCH}_{3}\right)$ and $\delta_{\mathrm{H}} 3.86\left(10-\mathrm{OCH}_{3}\right)$ suggested the two methoxy groups attached to $\mathrm{C}-1$ and $\mathrm{C}-10$, respectively. Thus, compound $\mathbf{1}$ was assigned as a new aprophine alkaloid with a given name Litsine A, as illustrated in Figure 1. 


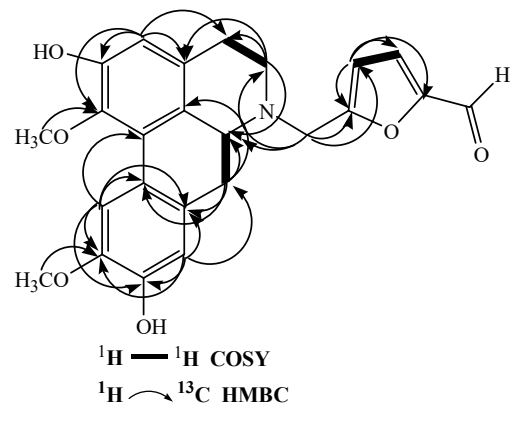

Figure 2. Key ${ }^{1} \mathrm{H}-{ }^{1} \mathrm{H}$ COSY and $\mathrm{HMBC}$ correlations of compound 1

Compounds 1-3 were tested for their effects on stimulating glucose uptake in $\mathrm{C} 2 \mathrm{C} 12$ myotubes. These results showed that the three compounds increased the glucose uptake potently and $\mathbf{1}$ exhibited the best activity as shown in Figure 3 .

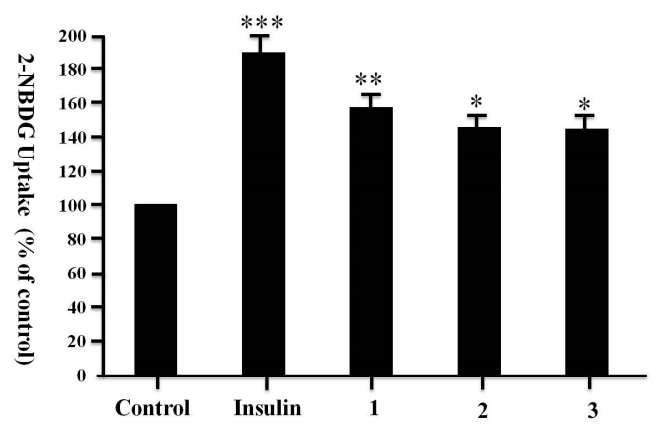

Figure 3. Effects of compounds $\mathbf{1 - 3}$ on glucose uptake in $\mathrm{C} 2 \mathrm{C} 12$ myotubes

\section{Acknowledgments}

This work was partially supported by the National Natural Science Fund for the National Science Foundation of China (No. 81460591, 81202994).

\section{Supporting Information}

Supporting Information accompanies this paper on http://www.acgpubs.org/journal/recordsof-natural-products

\section{ORCID}

Yan Jin: 0000-0002-3298-1822

Younan Wu: 0000-0003-4524-815X

Yiying Li: 0000-0001-6855-522X

Caiyun Zhang: 0000-0002-4432-5320

Wanying Sun: 0000-0002-1157-5489

Lin Dong: 0000-0003-0877-349X

Xiaopo Zhang: 0000-0003-2614-7425 


\section{References}

[1] S. Castro-Saavedra, G. Fuentes-Barros, C. Tirapegui, W. Acevedo-Fuentes, B. Cassels, A. Barriga and M. Vilches-Herrera (2016). Phytochemical analysis of alkaloids from the Chilean endemic tree Cryptocarya alba, J. Chil. Chem. Soc. 61, 3076-3080.

[2] D. Hughes, K. Genest and W. Skakum (1968). Alkaloids of Peumus boldus. Isolation of laurotetanine and laurolitsine, J. Pharm. Sci. 57, 1619-1620.

[3] G.D. Kong, Y. Zhao, H.G. Li, B. J. Chen, X.N. Wang, H.L. Zhou, X.H. Lou, M.D. Ren and T. Shen (2015). The genus Litsea in traditional Chinese medicine: an ethnomedical, phytochemical and pharmacological review, J. Ethnopharmacol. 164, 256-264.

[4] R. Bhowmick, M.S. Sarwar, S.M. Dewan, A. Das, B. Das, M.M. Uddin and M.S. Islam (2014). In vivo analgesic, antipyretic, and anti-inflammatory potential in Swiss albino mice and in vitro thrombolytic activity of hydroalcoholic extract from Litsea glutinosa leaves, Biol. Res., 47, 56-63.

[5] S. Mandal, C. Kumar, A. Majumder, R. Majumder and B. Maity (2000). Antibacterial activity of Litsea glutinosa bark, Fitoterapia 71, 439-41

[6] Y.S. Wang, R. Huang, H.Lu, F.Y. Li and J.H. Yang (2010). A new 2'-oxygenated flavone glycoside from Litsea glutinosa (Lour.) C. B. Rob., Biosci. Biotechnol. Biochem. 74, 652-654.

[7] D. Das, S. Maiti, T. Maiti and S. S. Islam (2013). A new arabinoxylan from green leaves of Litsea glutinosa (Lauraeae): structural and biological studies, Carbohydr. Polym. 92, 1243-1248.

[8] N. Agrawal, D. Pareek, S. Dobhal, M. Sharma, Y. Joshi and M. Dobhal (2013). Butanolides from methanolic extract of Litsea glutinosa, Chem. Biodivers. 10, 394-400.

[9] Y.N. Wu, Y.Jin, L. Dong, Y.Y. Li, C.Y. Zhang, M. Gui and X.P. Zhang (2017). New lignan glycosides from the root barks of Litsea glutinosa, Phytochemistry lett. 20, 259-262.

[10] Y.N. Wu, L. Dong, Y.Y. Li, Y.F. Tan, Y. Jin, Y.B. Li and X.P. Zhang (2017). Chemical constituents from bark of Litsea glutinosa and their antidiabetic targets, Mod. Chin. Med.19: 956-959.

[11] X.P. Zhang, C.Y. Chen, Y.Y. Li, D.L. Chen, L. Dong, W. Na, C.M. Wu, J.Q. Zhang, and Y.B. Li (2016). Tadehaginosides A-J, phenylpropanoid glucosides from Tadehagi triquetrum, enhance glucose uptake via the upregulation of PPAR $\gamma$ and GLUT-4 in C2C12 myotubes, J. Nat. Prod. 79, 1249-1258.

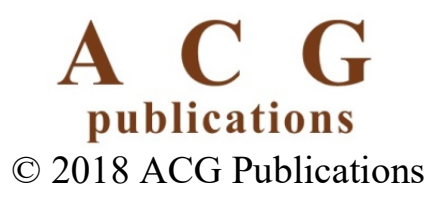

